er bargaining units ${ }^{22}$ it should act to protect the integrity of the association and the system, and that this requires recognition of the lockout power. Joint bargaining involves a bargaining relationship between a single union and a single collective employer. Absent a lockout power, the employers will be unable to preserve the integrity of their association since the union will deliberately create an artificial bargaining impasse in order to pick off the employers one by one whenever such a move suits its purpose. It was apparently this consideration which prompted Chairman Herzog to change his position and to urge the legality of the defensive lockout. ${ }^{23}$ As Herzog pointed out in his dissenting opinion in the Davis case, it is the union which takes "the initiative in selecting the particular weapons of economic combat," and the employers, by means of the lockout, can only "defend themselves with commensurate weapons." 24 Proscription of this defense will result in a multiemployer unit which the union can disregard at will, thus retaining the form but not the substance of multiemployer bargaining. On the other hand, sanction of the lockout power would not only be consistent with the Board's recognition of multiemployer units but would, insofar as it strengthens single employers, tend to offset labor's bargaining advantage and thus would be consistent with the overall objective of the Taft-Hartley Act. $^{25}$

\title{
THE NORRIS-LA GUARDIA ACT AND ERIE RAILROAD CO. V. TOMPKINS
}

An interesting but little explored aspect of the Norris-La Guardia Act ${ }^{1}$ is the possibility that certain of its provisions are unconstitutional under the doctrine of Erie R. Co. v. Tompkins. ${ }^{2}$ The stated object of the Erie decision was to prevent

22 It should be noted that the Board first sanctioned multiemployer bargaining units as early as 1938. See NLRB, 4th Annual Report 92-93 (1939), and cases cited ibid., in notes 82 and 83. Section 9(b), as originally enacted in the Wagner Act, 49 Stat. 453 (1935), 29 U.S.C.A. $\$ 159$ (b) (1947), provided the basis for such determinations. The provision was re-enacted with only a few qualifications not pertinent to this point in the Taft-Hartley Act, 61 Stat. 143 (1947), 29 U.S.C.A. §159(b) (Supp., 1951).

${ }^{23}$ Chairman Herzog signed the Board's original decisions in both the Morand and Davis cases. When the Morand case was returned to the Board on remand from the Seventh Circuit court, however, Herzog refrained from joining in the Board's dictum on the illegality of the defensive lockout, though he signed the decision. See Morand Bros. Beverage Co., 2 CCH Lab. L. Rep. $\{11,646,99$ N.I.R.B. No. 55, at 16 n. 20 (1952). When the Davis case was returned to the Board on remand from the Ninth Circuit court, Herzog's reservation of opinion turned into direct opposition to the majority's position, expressed in a brief dissenting opinion. See Davis Furniture Co., 2 CCH Lab. I. Rep. $\llbracket 11,812$, 100 N.L.R.B. No. 158, at 8 (1952).

${ }^{24}$ Chairman Herzog, dissenting, in Davis Furniture Co., 2 CCH Lab. L. Rep. $¥ 11,812,100$ N.L.R.B. No. 158 , at 8 (1952).

${ }^{25}$ See National Labor Relations Act, at $\S 1$, as amended, 61 Stat. 136 (1947), 29 U.S.C.A. $\S 151$ (Supp., 1951). See also Leonard v. NLRB, 197 F. 2d 435, 438-39 (C.A. 9th, 1952).

147 Stat. 70 (1932), 29 U.S.C.A. $\$ \$ 101-15$ (1947).

2304 U.S. 64 (1938). The problem was hinted at by Clark, State Law in the Federal Courts: The Brooding Omnipresence of Erie v. Tompkins, 55 Yale L.J. 267 (1946). An attempt to re- 
judicial discrimination in favor of nonresidents of a state who made use of federal diversity jurisdiction to gain an advantage from favorable federal rules. ${ }^{3}$ To attain this object, the Erie case required the federal courts in diversity cases to follow the substantive law of the states in which they sat. This rule eliminated the inducement to use federal courts for the purpose of obtaining decisions which would not be forthcoming in the state courts of the same state.

The Norris-La Guardia Act creates just such an inducement. By prohibiting federal courts from granting injunctive relief in certain cases arising out of labor disputes, it makes unavailable in federal courts an injunctive remedy which is available in some state courts. ${ }^{4}$ Since federal jurisdiction under the Norris-La Guardia Act is based solely on diversity of citizenship, ${ }^{5}$ the likelihood of a substantial difference in the outcome of a case in the federal as against the state court creates precisely the disuniformity of decision which the Erie doctrine seeks to prevent. ${ }^{6}$

The conflict between the Norris-La Guardia Act and the Erie case cannot be summarily disposed of by a choice between the two federal policies involved. ${ }^{7}$

solve the conflict was made in 41 Col. L. Rev. 104 (1941), but the resolution was unsatisfactory. The question has not been raised in any of the post Erie cases which have arisen under the Norris-La Guardia Act. See e.g., Lauf v. Shinner, 303 U.S. 323 (1938); New Negro Alliance v. Sanitary Grocery Co., 303 U.S. 525 (1938); Brown v. Coumanis, 135 F. 2d 163 (C.A. 5th, 1943); Gomez v. United Office and Professional Workers of America, CIO, Local 16, 73 F. Supp. 679 (D.C. D.C., 1948); Matson Nav. Co. v. Seafarers International Union, 100 F. Supp. 730 (D.C. Md., 1952).

${ }^{3}$ Erie R. Co. v. Tompkins, 304 U.S. 64, 74 (1938).

1 Section 7 of the Norris-La Guardia Act, 47 Stat. 70 (1932), 29 U.S.C.A. \$ 101 (1947), provides that, "No court of the United States ... shall have jurisdiction to issue any restraining order or temporary or permanent injunction in a case involving or growing out of a labor dispute except in strict conformity with the provisions of this Act." Subsequent sections of the Act provide that no injunction shall issue unless the following facts are established: (1) irreparable injury to property will result; (2) unlawful acts have been committed and will continue to be committed; (3) greater injury will result to complainant by denial of relief than will result to defendants by granting relief; (4) there is no adequate legal remedy; (5) public officers charged with the duty of protecting complainant's property are unwilling or unable to do so.

${ }^{5}$ See S. S. Kresge Co. v. Amsler, 99 F. 2 d 503 (C.A. 8th, 1938); Grace Co. v. Williams, 96 F. 2d 478 (C.A. 8th, 1938); Rhode v. Dighton, 27 F. Supp. 149 (D.C. Mo., 1939).

- The Supreme Court has held that it is contrary to the policy of Erie v. Tompkins for federal courts, in diversity cases, to grant remedies which are not available in the state courts. Angel v. Bullington, 330 U.S. 183 (1947); Woods v. Interstate Realty Co., 337 U.S. 535 (1949). The Norris-La Guardia Act simply resulted in the converse of this situation-a remedy available in a state court is made unavailable in the federal courts. This situation is as inconsistent with the Erie doctrine as the situation presented in the Bullington case. It should be noted, however, that in the Bullington case there was no federal statute which expressly provided for the availability of the remedy in the federal courts, nor was there any conflict with the state policy. The Norris-La Guardia Act creates a conflict between state and federal policies in that the state remedy is withdrawn by federal statute. Regardless of whether this difference is sufficient to distinguish the Norris-La Guardia Act from the Bullington situation, the conflict with the Erie policy of uniformity persists.

7 The singular feature of the Act is that it lays down a federal policy in an act which ostensibly purports to limit federal jurisdiction. Cf. $\$ 101$ with the following: "[T]he public 
Mr. Justice Brandeis' dictum in the Erie decision, it has been argued, makes the Erie doctrine a constitutional mandate. This dictum declares that " $[\mathrm{t}] \mathrm{h}$ ere is no federal general Common Law. Congress has no power to declare substantive rules of Common Law applicable in a state." If Justice Brandeis' view is correct, Congress is precluded from prescribing, in diversity cases, common-law rules of decision for federal courts. Since the Norris-La Guardia Act in effect prescribes a substantive rule of decsion for diversity cases, its constitutionality is questionable under the Brandeis dictum. ${ }^{9}$

A suggestion for sustaining the constitutionality of the Norris-Ia Guardia Act, which is derived from a limitation upon the Erie doctrine contained in the Erie case itself, is unsatisfactory. The argument is that the Act is purely procedural. Since the Erie doctrine admittedly does not require conformity of

policy of the United States is hereby declared as follows: ... Wherefore he [the individual unorganized worker] should be free to decline to associate with his fellows, it is necessary that he have full freedom of association, self-organization, and designation of representatives of his own choosing, to regulate the terms of his own employment, and that he shall be free from the interference and restraint of the employers of labor, or their agents. . . . [T]herefore, the following definition of and limitation upon, the jurisdiction and authority of the courts of the United States are enacted." 47 Stat. 70 (1932), 29 U.S.C.A. § 102 (1940).

${ }^{8}$ Erie R. Co. v. Tompkins, 304 U.S. 64, 78 (1938). The Erie case overruled Swift v. Tyson, 16 Pet. (U.S.) 1 (1842). The Swift case was based on an interpretation of Section 34 of the Federal Judiciary Act, 1 Stat. 92 (1789), 28 U.S.C.A. $\$ 275$ (1940), which reads as follows: "The laws of the several states, except where the Constitution, treaties, or statutes of the United States otherwise require or provide, shall be regarded as rules of decision in trials at common law, in courts of the United States, in cases where they apply."

The majority of the Court in the Swift case interpreted this section as a requirement that the federal courts follow only the statutory law of the states. In matters of "general law," the Court felt that the federal courts were free to adopt independent rules of decision in the absence of state statutes. In another dictum which appeared in the Erie case, Justice Brandeis described this decision as an "unconstitutional usurpation of power by the courts of the United States which no lapse of time or respectable array of opinion ought to make us hesitate to correct." Tbid., at 79. The conclusion that must be drawn from this pronouncement is that Section 34 is declaration of a limitation upon the federal judiciary which is imbedded in the Constitution. According to this view, Section 34 requires the federal courts to follow not only state statutory law, but also state decisional law. Furthermore, Section 34 is merely a supererogation since, presumably, the limitation it imposes is already found in the Constitution.

Article III of the Constitution authorizes Congress to establish the federal courts and to determine their jurisdiction. It doesn't hint at the limitation suggested by Justice Brandeis. Presumably, Mr. Justice Brandeis was seeking to resolve the conflict between the limited powers of Congress on the one hand, and the wide powers of the federal judiciary on the other. See Herriott, Has Congress the Power To Modify the Effect of Erie v. Tompkins?, 26 Marquette L. Rev. 1 (1941).

9 The so-called "Yellow Dog" contract is rendered unenforceable by the Norris-La Guardia Act. 29 U.S.C.A. $\$ 103$ (1940). This is clearly a substantive rule applicable in all cases. It upsets the rules relating to the enforcement of valid contracts which were controlling prior to the Act. Hitchman Coal \& Coke Co. v, Mitchell, 245 U.S. 229 (1917); Eagle Glass Mfg. Co. v. Rowe, 245 U.S. 275 (1917). This section of the Act therefore flies in the teeth of the Brandeis dictum, but its constitutionality on this point has never been questioned. Other statutes have subsequently declared the illegality of the "Yellow Dog" contract. National Labor Relations Act of 1935, at $\$ 7$ (a), 49 Stat. 449 (1935), 29 U.S.C.A. \$ 158 (1940); Labor-Management Relations Act, Title I, § 8, 61 Stat. 146 (1947), 29 U.S.C.A. \& 158(a) (Supp., 1951). 
federal and state procedure, ${ }^{10}$ a procedural view of the Norris-La Guardia Act would avoid any conflict with the doctrine.

There are two decisive counter arguments. First, the Act has been held not to be susceptible of a strictly procedural interpretation. In United States v. Hutcheson, ${ }^{11}$ the Supreme Court argued with considerable vigor that the policy declaration of the Act ${ }^{12}$ required a substantive rather than procedural interpretation of its provisions. Though the Court was concerned only with the relation of the Act to federal regulation under the commerce power, ${ }^{13}$ the substantive interpretation could be extended to its other aspects. Second, even if the Act were on the borderline between substance and procedure, it would have to be characterized as substantive for the purposes of the Erie doctrine. It is now well settled that characterization of a borderline rule of law as procedural is inaccurate for purposes of the Erie doctrine if it leads to substantial disuniformity of result in state and federal forums. ${ }^{14}$

Another argument for upholding the constitutionality of the Norris-Ia Guardia Act is based on the so-called "jurisdictional" interpretation. ${ }^{15}$ For purposes of this argument, the term "jurisdiction" is broadened so as to signify the power of a court to grant an appropriate remedy. ${ }^{16}$ The reasoning is that if the

${ }^{10}$ Erie R. Co. v. Tompkins, 304 U.S. 64, (1938). See Wayman v. Southard, 10 U.S. 1 (1825).

"11 312 U.S. 219 (1941).

${ }^{12}$ See note 7 supra.

13 "Congress in the Norris-La Guardia Act expressed the Public Policy of the United States and defined its conception of a labor dispute in terms which no longer leave room for doubt.... The Norris-La Guardia Act reasserted the original provisions of the Clayton Act by infusing into it the immunized trade union activities as redefined by the later Act. In this light, sec. 20 removes all such allowable conduct from the taint of being a 'violation of the laws of the United States, including the Sherman Law.' " United States v. Hutcheson, 312 U.S. 219, 236 (1942).

${ }^{14}$ Sampson v. Channel, 110 F. 2d 754 (C.A. 1st, 1940); Guaranty Trust Co. v. York, 326 U.S. 99 (1945). In the latter case, Justice Frankfurter ruled that a statute of limitations, though normally characterized as procedural, was substantive for the purpose of the Erie doctrine. The state statute of limitations was applied in preference to the federal statute on grounds that application of the latter would result in a disposition of the case substantially different from that in the state court.

The same rationale was used to limit the doctrine of "Equitable Remedial Rights." This doctrine provided that in all equitable matters, the federal courts were free to dispose of cases without interference from state law. The status of this doctrine was naturally questionable after the decision of Erie v. Tompkins. Justice Frankfurter stated in the Guaranty case that as a result of the Erie case, the doctrine could not be employed where to do so would substantially change the result in the federal as against the state court. It is apparent, however, that considerable freedom is left to the federal judges in determining whether a result is or is not substantially different.

Despite the extension of the Erie case to equity in Ruhlin v. N.Y. Life Ins. Co., 304 U.S. 202 (1938), and the limits imposed by the Guaranty case, the doctrine of the Remedial Rights has shown surprising tenacity. See, e.g., Austrian v. Williams, 103 F. Supp. 64 (S.D.N.Y., 1952), where, in an action not based on diversity jurisdiction, the district court applied federal laches doctrines even though the action was based strictly on a state created right. This case, however, was recently reversed, 198 F. 2d 697 (C.A. 2d, 1952).

${ }^{15}$ See Substance and Procedure in Federal Equity - The Labor Injunction and the Stockholder's Suit, 41 Col. L. Rev. 104 (1941).

${ }^{16}$ Ibid., at note 35. 
power to grant the appropriate remedy is withdrawn, the court is justified in refusing to take cognizance of the case. If this reasoning were extended to cover the withdrawal of the injunctive remedy by the Norris-La Guardia Act, federal courts could simply refuse to take cognizance of suits for labor injunctions, remand the cases to the state courts, and Erie difficulties would be avoided. In the absence of a decision in the federal courts, there could be no conflict with the rulings of state courts or with state statutes.

"Authority" for the foregoing view may be found in an analogy to the treatment by federal courts of state statutes enlarging equitable jurisdiction. Federal courts have been reluctant to apply such statutes when they enlarge equitable jurisdiction to include cases previously tried at law. Prior to Erie, the practice of federal courts in such cases was to transfer the case to the law side of the court. If adequate legal remedies were unavailable, the case was remanded to the state court. ${ }^{17}$ The practice was justified on the ground that in the absence of an adequate legal remedy a final transfer to the law side would deprive the litigant of effective relief, and the courts preferred not to hear the case at all rather than upset the existing structure of federal equity. ${ }^{18}$ Similarly, it may be argued that federal courts should refuse to take cognizance of suits for labor injunctions rather than upset the existing uniformity doctrine of the Erie case..$^{19}$

Counter arguments are again decisive. The "jurisdictional" view would necessarily draw state law into the vacuum created by federal abstention, thus frustrating the purpose of the Act. It was the intent of Congress that the use of the labor injunction in the settlement of labor disputes be drastically curtailed. ${ }^{20}$ If the federal courts were to remand to the state courts all cases arising under the Norris-La Guardia Act, the use of the injunction would continue unabated. The "jurisdictional" question has been raised in several cases, but the federal courts have generally held that they have sufficient jurisdiction despite their inability to grant the injunctive remedy ${ }^{21}$ Furthermore, the Federal Removal

${ }^{17}$ Cates v. Allen, 149 U.S. 451 (1893). See also Rosenbaum v. Bauer, 120 U.S. 450 (1887)

18 Further justification for this interpretation of the Norris-La Guardia Act is the well known doctrine that a statute should be interpreted so as to avoid unconstitutionality. If the restriction on the remedial powers of the federal courts by the Act conflicts with the constitutional doctrine of Erie v. Tompkins, the "jurisdictional" interpretation of the Act should be adopted in order to avoid unconstitutionality. See Crowell v. Benson, 285 U.S. 22, 62 (1931); Ashwander v. TVA, 297 U.S. 288 (1936).

${ }^{19}$ Substance and Procedure in Federal Equity-The Labor Injunction and the Stockholders' Suit, 41 Col. L. Rev. 104, 120 (1941).

${ }^{20}$ Textile Workers Union of America v. Amazon Cotton Mill Co., 76 F. Supp. 159 (N.D. N.C., 1947); United States v. Brotherhood of Locomotive Engineers, 79 F. Supp. 485 (D.C. D.C., 1948), cert. denied, 335 U.S. 867 (1948).

${ }^{21}$ Miller Parlor Furniture Co. v. Furniture Workers' Industrial Union, 8 F. Supp. 209 (D.C. N.J., 1934); Levering \& Garrigues Co. v. Morrin, 71 F. 2d 284 (C.A. 2d, 1934).

Contra: Parsons v. Sinclair Refining Co., E.D. Okla., No. 2704 (March 14, 1950) (not reported). See also Wucker Furniture Co. v. Furniture Salesmens' Union, CIO, Local 853, 126 N.J. Eq. 145 (1939). 
Statute ${ }^{22}$ requires the federal courts to hear all cases when the requisites of federal jurisdiction (diversity of citizenship and jurisdictional amount) are satisfied. The cases indicate that only the minimum requisites of federal jurisdiction need be satisfied. The absence of power to grant a remedy available in the state court does not require a remand of the case to the state court. ${ }^{23}$

A somewhat more plausible argument for the compatibility of the Norris-La Guardia Act with the Erie case stems from the substantive interpretation of the Act. The rule of the Erie case clearly does not apply to actions brought under federal statutes enacted pursuant to constitutional grants of power such as the Sherman Act, ${ }^{24}$ or the Federal Communications Act. ${ }^{25}$ The courts have also refused to apply the Erie doctrine to actions brought to enforce state created rights and arising under diversity jurisdiction where enforcement of the rights would contravene the policy of a federal statute. ${ }^{26}$ Presumably, federal law will control in each kind of case even if it arises in a state court. ${ }^{27}$ Application of federal law in these cases does not, therefore, lead to disuniformity of decision.

Norris-La Guardia cases, it may be argued, are analogous to the cases in which application of the Erie rule would contravene the policy of a federal statute and the Erie doctrine should not therefore apply. This argument stumbles upon a constitutional objection. The Norris-La Guardia Act extends to all diversity cases, including those involving only intrastate commerce. Its policy would therefore be contravened whenever state created rights to injunctive remedies were enforced. The result, to preclude state courts from granting injunctive remedies in purely intrastate disputes which involve diversity of citizenship, would clearly be unconstitutional.

Despite the obvious substantive consequences of the Norris-La Guardia Act, both state and federal courts have indicated their disapproval of the foregoing analogy. They have repeatedly asserted that the Act affects neither state law nor the jurisdiction of state courts, though the analogy has never been pushed so far as to require an explicit treatment of the constitutional difficulty ${ }^{28}$ The

2262 Stat. 937 (1948), 28 U.S.C.A. \$1441(a) (Supp., 1951). "Except as otherwise provided by act of Congress, any civil action brought in a state court of which district courts of the United States have original jurisdiction, may be removed by the defendant or defendants to the district court of the United States to the district or division embracing the place where such action is pending."

${ }^{23}$ See, e.g., Tillman v. Russo Asiatic Bank, 51 F. 2d 1023 (C.A. 2d, 1931), cert. denied 285 U.S. 539 (1932); Rogge v. Michael Del Balso Inc., 15 F. Supp. 409 (D.C. N.Y. 1936).

2426 Stat. 209 (1890), as amended, 15 U.S.C.A. $\$ 1$ (1949).

${ }^{25} 48$ Stat. 1064 (1934), as amended, 47 U.S.C.A. $\$ 151$ (Supp., 1951).

${ }^{25}$ Sola Electric Co. v. Jefferson Electric Co., 317 U.S. 173 (1942); O'Brien v. Western Union Telegraph Co., 113 F. 2 d 539 (C.A. 1st, 1940). See also, Exceptions to Erie v. Tompkins: The Survival of Federal Common Law, 59 Harv. L. Rev. 966 (1946).

${ }^{27}$ Garrett v. Moore-MacCormack Co., 317 U.S. 239, 245 (1942). See also Claflin v. Houseman, 93 U.S. 130 (1876); Exceptions to Erie v. Tompkins: The Survival of Federal Common Law, 59 Harv. L. Rev. 966 (1946).

${ }^{28}$ Though the courts have not treated this argument explicitly, it is not likely that it would be acceptable. See e.g., Alesna v. Rice, 172 F. 2d 176 (C.A. 9th, 1939); International Long- 
procedural, "jurisdictional" and substantive interpretations thus fail to resolve the conflict between the Norris-La Guardia Act and the Erie doctrine.

The ultimate resolution of the conflict hinges upon a critical re-examination of the Erie case itself. For the purpose of this re-examination, it is necessary to refer not only to the dictum concerning the powers of Congress, but also to a second dictum which condemned Swift v. Tyson as an unconstitutional usurpation of powers by the federal courts and withdrew from them the power to adopt independent rules of decision in the area of "general law."29 The first dictum. precludes not only the courts but also Congress from prescribing substantive rules of decision for federal courts. Substantive rules enacted in pursuance to constitutional grants of power are of course excluded from the sweep of this dictum, but any attempt to implement a policy by extending or restricting the remedial powers of the federal courts, without reference to constitutional powers, might be unconstitutional under this dictum of the Erie case. ${ }^{30}$ Since there may be numerous federal policies that can be implemented only in this way, the constitutional basis of the dictum is a crucial question. The possibility that the dicta do not state constitutional doctrine but merely interpret a federal statute which is not declaratory of the Constitution, i.e., Section 34 of the Federal Judiciary Act, has been frequently noted and forcefully argued. ${ }^{31}$ It would fol-

shoremen's Union v. Wirtz, 170 F. 2d 183 (C.A. 9th, 1948); Southern Bus Lines v. Amalgamated Ass'n of Street etc., Ry. Employees, 205 Miss. 354, 38 So. 2d 765 (1949). The constitutional diffculty could be avoided if the courts heard only those cases involving interstate commerce, but the terms of the Act provided that no injunction shall be granted regardless of whether the dispute involves interstate or intrastate commerce. All diversity cases are included. See note 4 supra.

${ }^{29}$ See note 8 supra.

${ }^{30}$ A distinction should be drawn between the term "jurisdiction" and the term "remedial." Prior to the Erie case, the constitutionality of the Norris-La Guardia Act was successfully defended on the ground that Congress had the power to restrict or expand the "jurisdiction" of the federal courts. Levering \& Garrigues v. Morrin, 71 F. 2d 284 (C.A. 2d, 1934). If "jurisdiction" refers merely to the power of a court to hear certain kinds of cases, or to the geographical area in which its rulings are effective, then this argument would be a good defense against application of the Erie rule. Such a definition would place jurisdictional changes within the sphere of procedure. Restriction or expansion of the available remedies, however, can substantially affect the substantive law. The Norris-La Guardia Act deals with the remedial rather than with the "jurisdictional" powers of the federal courts. The decision in Angel v. Bullington, 330 U.S. 183 (1947), indicates that the Erie rule applies if difference in available remedies results in substantial disuniformity of decision. In view of the dicta in the Erie case, such remedial changes, when decreed by Congress, may be unconstitutional (if they apply only in diversity cases).

31 See the concurring opinion of Justice Reed in the Erie case, 304 U.S. 64 (1938). "I am not at all sure whether in the absence of statutory direction, federal courts would be compelled to follow state decisions. There was sufficient doubt about the matter in 1789 to induce the first Congress to legislate. No former opinions of this Court have passed on it.... If the opinion commits this Court to the position that Congress is without power to declare what rules of substantive law shall govern the federal courts, that conclusion also seems questionable. ... The Judiciary Article III, and the necessary and proper clause of Article I, sec. 8, may fully authorize such legislation as this sec. 34 of the Judiciary Act." See also, Cook, The Conflict of Laws in the Federal Courts, 36 III. L. Rev. 494 (1942); Constitutional Aspects of the Abolition of Federal Common Law, 1 La. L. Rev. 161 (1938). 
low from this view that Congress, by subsequent legislation, could amend or repeal the statutory limits on congressional and judicial power set forth in Section 34 .

Any appraisal of the dicta must begin with an analysis of Section 34. It has been pointed out that Justice Story's view was that the word "laws" did not include the decisions of state courts but referred only to statutory law. He further assumed that in the absence of any controlling state or federal legislation, the federal courts were free to adopt their own rules of decision in matters of "general law." Recent research indicates that prior to the Swift case, Story believed that the federal courts were possessed of even greater powers. The indications are that both Marshall and Story believed that the words "rules of decision" when read in conjunction with "laws of the several states" alluded not to the binding effect of law as specifically expressed in statutes or decisions, but to the techniques, methods and principles of the common law. ${ }^{32}$ According to this view, Section 34, in directing the federal courts to follow such "laws," did not require that federal courts follow the particular decisions of the state courts. They were bound only to follow the techniques and principles of decision which the state courts used in the absence of statutory law. ${ }^{33}$ The obvious inference from this interpretation is that Section 34 permitted the federal judiciary to adopt independent rules of decision except where Congress or the state legislatures otherwise directed. In other words, Section 34, in the view of Marshall and Story, is an example of Congress' exercise of its power to do what the legislature of any state is capable of doing, to wit: to amend common-law rules of decision by statute.

It is conceded, of course, that simply as a matter of sentence structure, Justice Brandeis' interpretation of Section 34 is not necessarily incorrect. The phrase, "laws of the several states," could undoubtedly refer to statutes and decisions of the states, but in the light of the historical background of the Constitution, it is equally possible-indeed more probable- that they refer to the techniques of the common law and to the judicial power implicit in its principles. $^{34}$

22 Cook, ibid.; Goodnow, Social Reform and the Constitution (1911).

${ }^{33}$ Justice Story's decision in Swift v. Tyson is actually in harmony with this interpretation of Section 34. One of the principles of the common law is that it can be amended by legislative action. When such action is taken, the courts are no longer free to adopt independent rules of decision. In cases arising under state statutes, the federal courts will apply the state statutes, since in so doing they are still following the techniques of decision used by the state courts. It is primarily for this reason that Justice Story required the federal courts to follow state statutory law. There are, of course, other reasons. Following the decisional law of the highest state tribunal would be a relatively simple matter, but the determination of the status of a decision in an intermediate state tribunal is difficult. What would the courts do in the absence of state decisions in particular kinds of cases? What is the status of an overruled or erroneous decision? These questions present only some of the difficulties which the courts must face in following state decisional law.

34 Cook, op. cit. supra note 31. 
If, then, the federal courts are merely required to adopt common-law techniques rather than state decisions as rules of decision, Section 34 does not represent a constitutional limitation on congressional power to declare rules of decision for federal courts. These rules would be applicable in diversity cases and Section 34 itself is an excellent example of precisely such a rule of decision. ${ }^{35}$ If this view of Section 34 is correct, then both Brandeis' dicta are inaccurate. The course pursued in Sreift v. Tyson might be called erroneous but it was not unconstitutional. If the Marshall and Story analysis of Section 34 is accepted, then that course was not even erroneous.

Commentators and courts today tend to exclude the Erie decision from the realm of constitutional doctrine. The decision is said to correct Justice Story's interpretation of Section 34 by including within the meaning of the words "laws of the several states" the decisions as well as the statutes of the states. Under this interpretation, Mr. Justice Brandeis' result can be accepted without relying on the constitutional overtones in his opinion. Thus, though the analysis of Section 34 herein presented is not commonly accepted, the removal of the taint of unconstitutionality from the Swift case has somewhat softened the blow dealt to the power of the federal judiciary by the Erie case. Congress has the power to declare substantive common-law rules of decision for the federal courts. The Norris-La Guardia Act is an example of such a rule. There is nothing in the Constitution which can preverit Congress from enacting it.

Although the better view of the Erie case ${ }^{36}$ rejects the constitutional implication of its dicta, the conflict between the Norris-La Guardia Act and the Erie policy of uniformity persists. Though the Act is not unconstitutional, it must inevitably create disuniformity between federal and state rulings. Cases such as Angel v, Bullington ${ }^{37}$ have indicated that the Supreme Court is willing to sacrifice federal jurisdiction on the altar of uniformity, but in the Bullington case there was no specific federal law concerning jurisdiction to stay the Court's hand. In such a situation it may be wise to restrict federal jurisdiction in order to achieve uniformity. But where Congress has decreed disuniformity in order to effectuate a federal policy, the federal courts should not be bound by the Erie rule. The Norris-La Guardia Act, as a valid excercise of congressional power to prescribe a substantive rule of decision for the federal courts, is like an amendment to Section 34. Though a federal law which applies only in diversity cases may seem arbitrary, Congress is empowered to enact such a law. The power should be carefully and sparingly used, but the decision as to when and where to use it rests with Congress.

${ }^{35}$ See note 31 supra. Note that Justice Reed felt that Congress was authorized by the necessary and proper clause and the Judiciary Article to legislate with respect to diversity cases. He interpreted Section 34 as precisely this kind of legislation. Note also that the power of Congress to legislate with regard to admiralty is unquestioned. It is an example of how a judicial grant of power has been used to justify Congressional legislation. In re Garnett, 141 U.S. 1 (1891).

${ }^{36}$ See note 31 supra.

37330 U.S. 183 (1947). 